\title{
Peertechz
}

\section{Study of biochemical profile in tubercular pleural and peritoneal effusion in the sub- himalayan region patients}

\author{
Kiran Gupta ${ }^{1 \#}$, Ashraf Ali Khan ${ }^{2 *}$, Tariq Masood ${ }^{1}$ and \\ Waseem Feeroze Bhat ${ }^{2 *}$
}

${ }^{1}$ Shri Guru Ram Rai Institute of Medical \& Health Sciences and Shri Mahant Indiresh Hospital Patel Nagar, Dehradun (U.K) 248001, India

${ }^{2}$ Goverment Medical College Doda, Jammu and Kashmir -182202, India

"Equal contribution towards the article

Received: 30 September, 2020

Accepted: 12 October, 2020

Published: 13 October, 2020

*Corresponding author: Dr. Waseem Feeroze Bhat, Government Medical College Doda, Jammu and Kashmir 182202, India, Tel: Tel No: +919797130949;

E-mail: waseemfeeroze@uok.edu.in

Keywords: Tuberculosis; Pleural fluid; Peritoneal fluid; Tuberculous pleural effusion; Mycobacterium tuberculosis

https://www.peertechz.com

\begin{abstract}
Tuberculosis (TB) is a dangerous infection affecting about one third of the world population, despite the availability of affordable and effective chemotherapy, remaining one of the major causes of death from a single infectious agent worldwide. Here the measurement of ADA, LDH, protein and glucose has been advocated to help diagnose tuberculous pleural and peritoneal effusions in TB patients. Although considered definitive, microbiological tests have limited sensitivity and culture has to be prolonged for several weeks before being reported negative, in diagnosing tubercular pleural and peritoneal effusions and have more sensitivity and specificity as compared to pleural fluid culture and biopsy, and by estimation of values of these tests could be a useful tool for diagnosing tubercular pleural and peritoneal effusion. Thus a biochemical test is potentially useful, although high diagnostic accuracy is necessary.
\end{abstract}

\section{Abbreviations}

TB: Tuberculosis; MTB: Mycobacterium Tuberculosis; ADA: Adenosine Deaminase; LDH: Lactate Dehydrogenase

\section{Introduction}

Tuberculosis is (TB) highly contagious bacterial infection caused by bacteria called Mycobacterium tuberculosis (MTB), affecting about one third of the world population and remaining one of the major causes of deaths worldwide [1]. MTB infection can spread through the air from one person to another and causes active disease or latent infection [2]. MTB infection is preventable via Bacillus of Calmette and Guérin (BCG) vaccination and curable with antituberculous drugs. The clinical manifestations of tuberculosis are dependent on a number of factors: age, immune status, co-existing diseases, immunization status to the bacillus CalmetteGuerin (BCG); virulence of the infecting organism and hostmicrobe interaction [3]. If a TB infection does become active, it most commonly involves the lungs (in about $90 \%$ of cases). Symptoms may include chest pain and a prolonged cough producing sputum [4]. Tuberculosis may occur in any location from the mouth to the anus, although lesions proximal to the terminal ileum are unusual. The abdomen is the most common site of extrapulmonary tuberculosis, with peritoneal disease being the commonest form within the abdomen. Tuberculous ascites, one of the clinical signs of abdominal TB, implies accumulation of fluid in the abdomen, a swollen abdomen, and slightly raised tubercles of 1-2 mm all over the peritoneum [5].

The most common sites of extrapulmonary tuberculosis are the bones and joints, lymph nodes, abdomen, spinal cord, brain and pleura [2]. Among these sites the pleura provide useful information about the etiology of pleural effusion. Pleural effusions result from excessive fluid formation and its accumulation in the pleural space. The pleural effusion is likely a manifestation of paucibacillary mycobacterial infection within the pleural space [6]. Tuberculous pleural effusion (TPE) results from Mycobacterium tuberculosis infection of the 
pleura and is characterized by an intense chronic accumulation of fluid and inflammatory cells in pleural space [7]. In the context of present study different investigation have done in the tubercular pleural and peritoneal effusion to analyze the levels of ADA, total proteins, glucose and lactate dehydrogenase and comparison between tubercular pleural and peritoneal effusion in TB patients.

\section{Materials and methods}

The present study was conducted in 20 patients of tubercular pleural effusion (test group) and 40 patients of non-tubercular pleural effusion (control group) in the department of biochemistry and pulmonary medicine ward and 20 patients of peritoneal effusion (test group) and 40 patients of non-tubercular peritoneal effusion (control group) in the department of biochemistry and gasteroenterology ward of shri guru ram rai institute of medical and shri mahant indiresh hospital, dehradun during 2016 to 2018. The various biochemical investigations of these patients were assessed and compared to the normal controls. The pleural and peritoneal fluid was confirmed positive for mycobacterium tuberculosis during TB-PCR. Also the pleural and peritoneal fluid showed positive for Mycobacteria tuberculosis in Acid-Fast Bacillus (AFB) testing culture. The age groups of all the persons from 3-88 years were taken. Both the gender was taken.

\section{Methods}

Different tests were performed by employing various methods.

\section{Test for glucose}

VITROS Chemistry products glucose (GLU) slides quantitatively measure glucose concentration in serum, urine, and fluids using VITROS 250 AND 5, 1 FS Chemistry Systems and the VITROS 5600 Integrated Systems.

\section{Test type and conditions for glucose}

\begin{tabular}{|c|c|}
\hline Test type: & Colorimetric \\
\hline VITROS system: & 56000,5, IFS, 250 \\
\hline Approximate incubation time: & 5 minutes \\
\hline Temperature: & $37^{\circ} \mathrm{C}$ \\
\hline Wavelength: & $540 \mathrm{~nm}$ \\
\hline Reaction sample volume: & $10 \mu \mathrm{L}$ \\
\hline
\end{tabular}

\section{Reaction sequence}

$\beta$-D-glucose $+\mathrm{O}_{2}+\mathrm{H}_{2} \mathrm{O}$....Glucose oxidase... D-gluconic acid $+\mathrm{H}_{2} \mathrm{O}_{2}$

$2 \mathrm{H}_{2} \mathrm{O}_{2}+4$-aminoantipyrine $+1,7-$ dihydronapthalenered. Peroxidase..Quinoneimine $+4 \mathrm{H}_{2} \mathrm{O}$

\section{Test for protein}

VITROS Chemistry products PROT slides quantitatively measure protein concentration in fluid using VITROUS 250 and 5, 1 FS chemistry systems and the VITROS 5600 integrated system.
Test type and conditions for protein

\begin{tabular}{|c|c|}
\hline Test type: & Colorimetric \\
\hline VITROS system: & $56000,5, I F S, 250$ \\
\hline Approximate incubation time: & 5 minutes \\
\hline Temperature: & $37^{\circ} \mathrm{C}$ \\
\hline Wavelength: & $670 \mathrm{~nm}$ \\
\hline Reaction sample volume: & $10 \mu \mathrm{L}$ \\
\hline
\end{tabular}

\section{Reaction sequence}

$\mathrm{Cu}^{2+}$-azo dye complex + protein...LiOH.. $\mathrm{Cu}^{2+}$-protein complex + azo dye

\section{Test for adenosine deaminase (ADA)}

MICROXPRESS ADA-MTB is a reagent for laboratory use only.

ADA-MTB comprises of:

a) Level 1 (L1) - ADA-MTB Reagent - Buffer Reagent.

b) L2- ADA-MTB Reagent - Adenosine Reagent.

c) L3- ADA-MTB Reagent - Phenol Reagent.

d) L4- ADA-MTB Reagent - Hypochlorite Reagent.

e) S- ADA-MTB Standard -ADA Standard.

\section{Reaction sequence}

Adenosine $+\mathrm{H}_{2} \mathrm{O} \ldots$ ADA.... Ammonia + Inosine

Ammonia + Phenol + Hypochlorite... Alkaline Medium...Blue Indophenol Complex

\section{Test for LDH}

The VITROS LDH slide method is performed using the VITROS LDH Slides and the VITROS Chemistry Products Calibrator Kit 3 on VITROS Chemistry Systems. The VITROS LDH Slide is a multilayered, analytical element coated on a polyester support.

A drop of patient sample is deposited on the slide and is evenly distributed by the spreading layer to the underlying layers. Lactate dehydrogenase catalyzes the conversion of pyruvate and $\mathrm{NADH}$ to lactate and $\mathrm{NAD}^{+}$. The oxidation of $\mathrm{NADH}$, which is monitored by reflectance spectrophotometry is used to measure lactate dehydrogenase activity.

\section{Reaction sequence}

Pyruvate $+\mathrm{NADH}+\mathrm{H}^{+} \ldots . . L D H . .$. Lactate $+\mathrm{NAD}^{+}$

\section{Test type and Conditions for LDH}

\begin{tabular}{|c|c|}
\hline Test type: & Multiple-point rate \\
\hline VITROS system: & 5,1 FS, 950, 750, 550, 250 \\
\hline Approximate incubation time: & 5 minutes \\
\hline Temperature: & $37^{\circ} \mathrm{C}$ \\
\hline Wavelength: & $340 \mathrm{~nm}$ \\
\hline Reaction sample volume: & $11 \mu \mathrm{L}$ \\
\hline
\end{tabular}




\section{Observations and results}

The various biochemical investigations of these patients were assessed and compared to the normal controls.

\section{Comparison of pleural fluid ADA, glucose, protein and LDH levels in the test group and control group}

Pleural fluid serves a physiologic function in respiration, while also being a useful measure to diagnose and assess disease, TB, and other abnormalities. Many conditions can cause problems within the pleural cavity and in the pleural fluid [8]. Fluid analysis can determine the cause of the effusion and abnormalities.

In the context of present study pleural fluid analysis in the TB patients were examined. Different parameters (ADA, glucose, protein and $\mathrm{LDH}$ ) were taken to analysis the concentration as compared to the control groups to distinguish them from $\mathrm{TB}$ patients. The observed mean \pm SD of $A D A$, glucose, protein and LDH in tubercular pleural effusion cases were $84.81 \pm 44.55$ $\mathrm{IU} / \mathrm{L}, 80.73 \pm 42.2 \mathrm{mg} / \mathrm{dL}, 4.67 \pm 0.9 \mathrm{gm} / \mathrm{dL}$ and $3404.2 \pm 9201.67$ $\mathrm{IU} / \mathrm{L}$ respectively whereas the mean $\pm \mathrm{SD}$ in non-tubercular pleural effusion were $51.43 \pm 42.32 \mathrm{IU} / \mathrm{L}, 94.72 \pm 45.82 \mathrm{mg} /$ $\mathrm{dL}, 4.07 \pm 0.94 \mathrm{gm} / \mathrm{dL}$ and $783.85 \pm 933.53 \mathrm{IU} / \mathrm{L}$. The P-value for each parameter was calculated as $0.0009,0.1595,0.0237$ and 0.0770 respectively, as shown in the Table 1 and Figure 1. The difference of ADA and proteins in the test group and control group was found to be significant and the difference of glucose and LDH in the test group and control group was not statistically significant.

\section{Comparison of peritoneal fluid ADA, glucose, protein and LDH levels in the test group and control group}

Peritoneal fluid is a liquid made in the abdominal cavity which lubricates the surface of tissue that lines the abdominal wall and pelvic cavity. There are many reasons for fluid accumulation, but the clinical presentation of TB ascites is challenging.

Here the various parameters were chosen in the TB patients to correlate with the control groups. In the context of present study the observed mean \pm SD of ADA, glucose, protein and LDH in tubercular peritoneal effusion cases were $111.47 \pm 98.33$ $\mathrm{IU} / \mathrm{L}, 54.15 \pm 26.26 \mathrm{mg} / \mathrm{dL}, 4.92 \pm 1.67 \mathrm{gm} / \mathrm{dL}$ and $574.8 \pm 186.54$ $\mathrm{IU} / \mathrm{L}$ respectively whereas the mean $\pm \mathrm{SD}$ in non- tubercular peritoneal effusion were $12.9 \pm 11.58 \mathrm{IU} / \mathrm{L}, 122.8 \pm 78.94 \mathrm{mg} /$ $\mathrm{dL}, \quad 2.49 \pm 0.91 \mathrm{gm} / \mathrm{dL}$ and $77.7 \pm 16.57 \mathrm{IU} / \mathrm{L}$. The P-value for each parameter was calculated as $0.000,0.0007,0.0001$ and 0.0001 respectively, as shown in the Table 2 and Figure 2. The difference of ADA, protein and LDH in the test group and control group was found to be highly significant.

\section{Comparison between pleural fluid and peritoneal fluid of ADA, glucose, protein and LDH levels in the test group}

Finally the above determined parameters were compared in the pleural and peritoneal fluids of the test groups. As determined from the above data the observed mean $\pm S D$ of $\mathrm{ADA}$, glucose, protein and LDH in tubercular pleural effusion
Table 1: Comparision of pleural fluid ADA, glucose, protein and LDH levels in the test group and control group.

\begin{tabular}{|c|c|c|c|c|c|}
\hline Parameter & $\begin{array}{c}\text { Test group } \\
(\boldsymbol{n = 4 0 )}\end{array}$ & $\begin{array}{c}\text { Control group } \\
(\boldsymbol{n}=\mathbf{4 0})\end{array}$ & $\boldsymbol{t}$-value & $\boldsymbol{p}$-value & $\begin{array}{c}\text { Level of } \\
\text { significance }\end{array}$ \\
\hline MDA $(\mathrm{IU} / \mathrm{L})$ & $84.81 \pm 44.55$ & $51.43 \pm 42.32$ & -3.436 & 0.0009 & $\mathrm{~S}$ \\
\hline Glucose $(\mathrm{mg} / \mathrm{dL})$ & $80.73 \pm 42.2$ & $94.72 \pm 45.82$ & 1.420 & 0.1595 & $\mathrm{NS}$ \\
\hline Protein $(\mathrm{gm} / \mathrm{dL})$ & $4.67 \pm 0.94$ & $4.07 \pm 1.35$ & -2.307 & 0.0237 & $\mathrm{~S}$ \\
\hline LDH $(\mathrm{IU} / \mathrm{L})$ & $3404.2 \pm 9201.67$ & $783.85 \pm 933.53$ & -1.792 & 0.0770 & $\mathrm{NS}$ \\
\hline
\end{tabular}

S: Significant; NS: Non significant

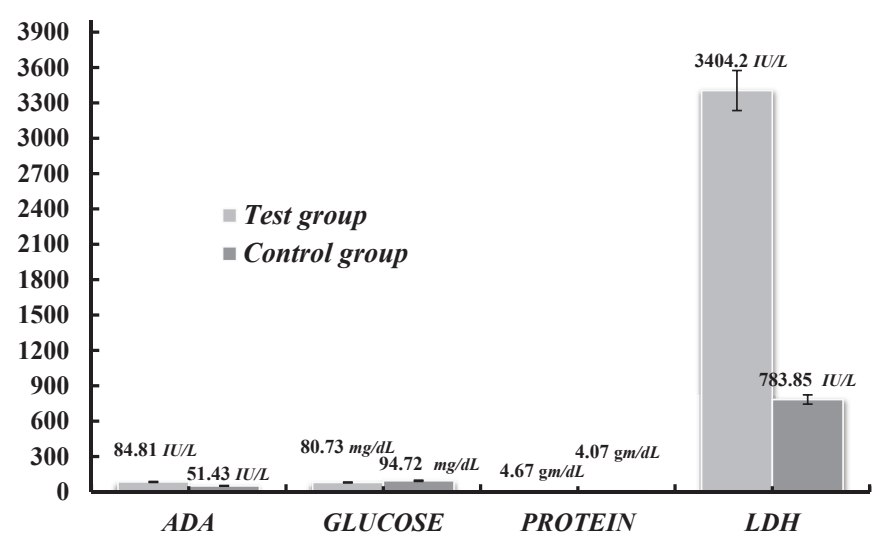

Figure 1: Different parameters (ADA, glucose, protein and LDH) of pleural fluid were taken to analysis the concentration as compared to the control groups to distinguish them from TB patients.

Table 2: Comparison of peritoneal fluid ADA, glucose, protein and LDH levels in the test group and control group.

\begin{tabular}{|c|c|c|c|c|c|}
\hline Parameter & $\begin{array}{l}\text { Test group } \\
\qquad(n=20)\end{array}$ & $\begin{array}{l}\text { Control group } \\
\qquad(n=20)\end{array}$ & t-value & p-value & $\begin{array}{c}\text { Level of } \\
\text { significance }\end{array}$ \\
\hline & \multicolumn{2}{|c|}{ Mean $\pm S D$} & & & \\
\hline$A D A(I U / L)$ & $111.47 \pm 98.33$ & $12.9 \pm 11.58$ & -4.453 & 0.0001 & HS \\
\hline $\begin{array}{c}\text { Glucose }(m g / \\
d L)\end{array}$ & $54.15 \pm 26.26$ & $122.8 \pm 78.94$ & 3.690 & 0.0007 & S \\
\hline $\begin{array}{c}\text { Protein }(\mathrm{gm} / \\
\mathrm{dL})\end{array}$ & $4.92 \pm 1.67$ & $2.49 \pm 0.91$ & -5.714 & 0.0001 & HS \\
\hline$L D H(I U / L)$ & $574.8 \pm 186.54$ & $77.7 \pm 16.57$ & -11.871 & 0.0001 & $\mathrm{HS}$ \\
\hline
\end{tabular}

700

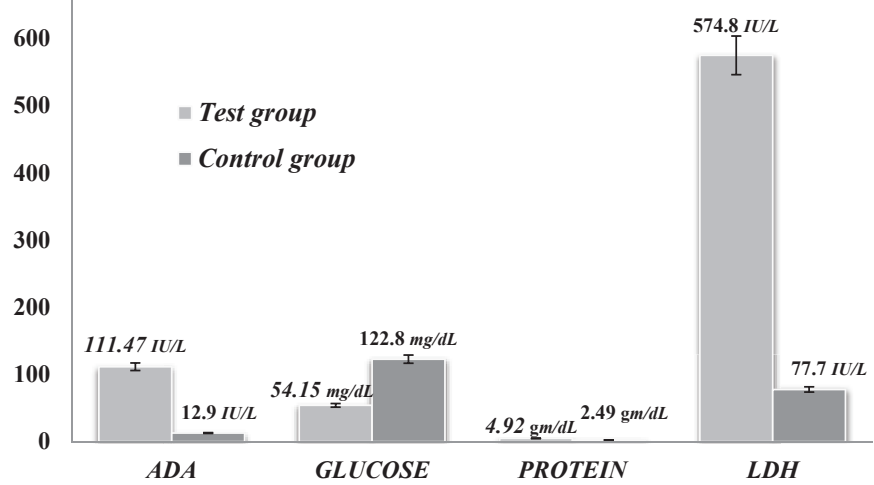

Figure 2: Peritoneal fluid analysis with reference to the ADA, glucose, protein and LDH levels in the test and control groups were compared. 
cases were $84.81 \pm 44.55 \mathrm{IU} / \mathrm{L}, 80.73 \pm 42.2 \mathrm{mg} / \mathrm{dL}, 4.67 \pm 0.9$ $\mathrm{gm} / \mathrm{dL}$ and $3404.2 \pm 9201.67 \mathrm{IU} / \mathrm{L}$ respectively whereas the mean \pm SD in tubercular peritoneal effusion were $111.47 \pm 98.33$ $\mathrm{IU} / \mathrm{L}, 54.15 \pm 26.26 \mathrm{mg} / \mathrm{dL}, 4.92 \pm 1.67 \mathrm{gm} / \mathrm{dL}$ and $574.8 \pm 186.54$ IU/L respectively as shown in Table 3 and in Figure 3. The $\mathrm{P}$-value for each parameter was calculated as $0.1522,0.0123$, 0.4602 and 0.1762 respectively. However, In the present study the comparison between tubercular pleural and tubercular peritoneal effusion was significant statistically only for glucose $(\mathrm{p}=0.0123)$ and the difference of ADA, protein and LDH in the test group of pleural effusion and test group of peritoneal effusion was not statistically significant.

Table 3: Comparison between pleural fluid and peritoneal fluid of ADA, glucose, protein and LDH levels in the test group.

\begin{tabular}{|c|c|c|c|c|c|}
\hline Parameter & $\begin{array}{c}\text { Test group } \\
\text { (pleural fluid) } \\
n=40)\end{array}$ & $\begin{array}{l}\text { Test group } \\
\text { (peritoneal } \\
\text { fluid) } n=20 \text { ) }\end{array}$ & t-value & p-value & $\begin{array}{c}\text { Level of } \\
\text { significance }\end{array}$ \\
\hline & \multicolumn{2}{|c|}{ Mean $\pm S D$} & & & \\
\hline$A D A(I U / L)$ & $84.81 \pm 44.55$ & $111.47 \pm 98.33$ & 1.451 & 0.1522 & NS \\
\hline Glucose $(m g / d L)$ & $80.73 \pm 42.2$ & $54.15 \pm 26.26$ & -2.583 & 0.0123 & S \\
\hline Protein $(\mathrm{gm} / \mathrm{dL})$ & $4.67 \pm 0.94$ & $4.92 \pm 1.67$ & 0.743 & 0.4602 & NS \\
\hline$L D H(I U / L)$ & $3404.2 \pm 9201.67$ & $574.8 \pm 186.54$ & -1.369 & 0.1762 & NS \\
\hline
\end{tabular}

S: Significant; NS: Non significant

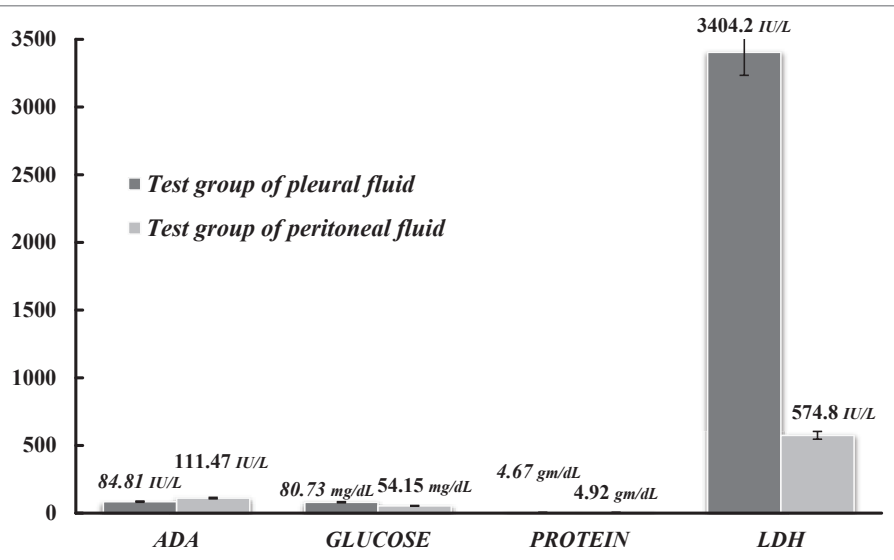

Figure 3: Comparison in the parameters of ADA, glucose, protein and LDH levels between pleural fluid and peritoneal fluids among the test group.

\section{Discussion}

Tuberculosis (TB) is the leading death cause in developing countries. Majority of TB patients involve the pulmonary TB. However, extrapulmonary TB involves the pleura and can affect any organ system, including the cardiovascular system, Central Nervous System (CNS) and gastrointestinal (GI) tract [9]. However, infection of the pleura in TB is common and the peural effusion, as an isolated manifestation of TB if ignored and having little immediate concern, can lead to serious disease many years later. In the context of present study, 40 positive controls of tubercular pleural effusion patients and 20 positive controls of tubercular peritoneal effusion patients were taken from the patients of tubercular and non-tubercular pleural and peritoneal effusion. In these patients the levels of ADA, Glucose, Protein, LDH were estimated. In countries with a high incidence of tuberculosis, measurement of ADA may be a helpful screening test. A value of ADA higher than $0.40 \mathrm{uKat} / \mathrm{l}$ has $100 \%$ sensitivity and a specificity of $99 \%$ for diagnosing tuberculous peritonitis [10]. Ascitic fluid adenosine deaminase activity (ADA) is considered a more sensitive and specific method used for early diagnosis of TB ascites. Even if the full physiological role of ADA is not yet completely understood, it is known that ADA values are notably higher $(>40 \mathrm{U} / \mathrm{L})$ in patients with TB ascites [11].

In the present study, we observed that the mean $\pm S D$ of ADA and protein in pleural fluid which was calculated to be as $84.81 \pm 44.55 \mathrm{IU} / \mathrm{L}, 4.67 \pm 0.94 \mathrm{gm} / \mathrm{dL}$ in test group and $51.43 \pm 42.32 \mathrm{IU} / \mathrm{L}, 4.07 \pm 1.35 \mathrm{gm} / \mathrm{dL}$ in control group and the $\mathrm{P}$-valves were found to be 0.0009 and 0.0237 , that indicated it was significant. Whereas, it was found to be highly significant in tubercular peritoneal effusion cases mean \pm SD of ADA in test group was found to be $111.47 \pm 98.33 \mathrm{IU} / \mathrm{L}$ and $12.9 \pm 11.58 \mathrm{IU} / \mathrm{L}$ in control group. The P-value was calculated as 0.000. Same results were found by Mathur et al. that the mean \pm SD of ADA in tubercular pleural effusion (TPE) cases was $88 \pm 38.91 \mathrm{IU} / \mathrm{L}$ and in non-TPE cases was $51.43 \pm 42.32 \mathrm{IU} / \mathrm{L}(\mathrm{P}=0.001)$. Also Gupta et al. observed that the mean \pm SD of ADA in TPE cases was $67.34 \pm 22.85 \mathrm{IU} / \mathrm{L}$ and in non- TPE cases was $18.60 \pm 9.12$ $\mathrm{IU} / \mathrm{L}(\mathrm{P}=0.0007)[12,13]$. Somewhat similar results were found by Gupta et al. in case of tubercular i.e. $4.3 \pm 0.9 \mathrm{gm} / \mathrm{dL}$ protein and in non tubercular it was $4.1 \pm 1.2 \mathrm{gm} / \mathrm{dL}$ [13]. In both cases pleural and peritoneal fluids ADA and protein were raised as compared to control groups but in case of peritoneal fluid both ADA and protein was increased as compared to pleural fluid. In the present study the level of ADA was found to be highly significant $(\mathrm{P}=0.0001)$ with the studies of Mathur. P.C. et al and Gupta et al [12,13]. Excess hydrostatic pressure developed in the pulmonary capillaries is the main cause for the Pleural effusions and then protein and cell rich fluid enters the pleural space through leaky capillary and pleural membranes with impaired by compromised lymphatic drainage. ADA in tuberculous effusions is thought to arise from activated monocytes and macrophages in the granulomatous lesions. ADA levels are most useful when there is a moderate to high suspicion of TB in patients with negative pleural fluid or biopsy cultures, and non-diagnostic histology [14]. ADA estimation being a simple, rapid and low should become an easy for the diagnostic work up of pleural effusions in tuberculosis cases.

Simultaneously, glucose and LDH were estimated in control as well as in test groups. In both cases pleural and peritoneal fluids glucose concentration was less in test groups as compared to control groups. In pleural fluid the mean $\pm S D$ value for glucose in test group was $80.73 \pm 42.2 \mathrm{mg} / \mathrm{dL}$ and for control $94.72 \pm 45.82 \mathrm{mg} / \mathrm{dL}$. In case of peritoneal fluid the mean \pm SD value for glucose in test group was $54.15 \pm 26.26 \mathrm{mg} /$ $\mathrm{dL}$ and for control $122.8 \pm 78.94 \mathrm{mg} / \mathrm{dL}$. Glucose concentration decreases due to consumption by bacteria, white blood cells, or cancer cells in the fluid in TB peritonitis. Glucose concentration is lower than normal in TB ascites, which makes it an indicator in differentiating tuberculosis from other diseases, such as cirrhosis. The ascitic/blood glucose ratio is a useful test in differentiating TB peritonitis from other causes of ascites [15]. 
The mean \pm SD of LDH in tubercular pleural effusion cases was $3404.2 \pm 9201.67 \mathrm{IU} / \mathrm{L}$, whereas the mean $\pm \mathrm{SD}$ in non- tubercular pleural effusion cases was $783.85 \pm 933.53 \mathrm{IU} / \mathrm{L}$. The P-value for LDH parameter was calculated as 0.0770 . The difference of glucose and LDH in the test group and control group was not statistically significant. The mean \pm SD of in tubercular peritoneal effusion cases was $574.8 \pm 186.54 \mathrm{IU} / \mathrm{L}$, whereas the mean $\pm \mathrm{SD}$ in non- tubercular peritoneal effusion was $77.7 \pm 16.57 \mathrm{IU} / \mathrm{L}$. The $\mathrm{P}$-value for $\mathrm{LDH}$ parameter was calculated as 0.0001. The comparison between tubercular pleural and tubercular peritoneal effusion was significant statistically only for glucose $(p=0.0123)$ and for LDH in the test group of pleural effusion and test group of peritoneal effusion was not statistically significant. This signifies that in both pleural as well as peritoneal cases the LDH value increased as compared to control groups. Gupta B. K. et al found the mean \pm SD of $\mathrm{LDH}$ in TPE cases was $151.6 \pm 27 \mathrm{IU} / \mathrm{L}$ and $147.4 \pm 18.6 \mathrm{IU} / \mathrm{L}(\mathrm{P}=0.5621)$ in non TPE cases [13]. In the present study the level of LDH was found to be non-significantly similar to the above studies. LDH measurement in body fluids may be used to differentiate the transudative and exudative effusions as LDH activity is considered an indicator of the extent of inflammation caused by bacterial infection or tissue damage. Measurement of lactate dehydrogenase (LDH) is found to be helpful, particularly in detecting the bacterial infection. Peritoneal fluid LDH above $220 \mathrm{IU} / \mathrm{L}$ suggests secondary, rather than spontaneous bacterial peritonitis, in conjunction with other laboratory, imaging, and clinical findings $[16,17]$. The pleural fluid lactate dehydrogenase (LDH) level in pulmonary bacterial infections is elevated in approximately $75 \%$ of cases, with levels commonly exceeding $500 \mathrm{IU} / \mathrm{L}$ [18]. LDH is a frequently used biomarker for various diseases. In case of TB it is very important for differentiating pleural fluid LDH level and might be of specific diagnostic significance. We found that the pleural fluid LDH level was significantly higher and an even greater difference was evident when were compared with the peritoneal fluid LDH. This signifies that pleural fluid study could be the early diagnostic tool for detecting the MTB infection. In view of the using ADA, protein, sugar and LDH levels in pleural and peritoneal fluid for differentiating between test and control groups, we detected that glucose and LDH levels were found higher in pleural fluid $(80.73 \pm 42.2 \mathrm{mg} / \mathrm{dL}, 3404.2 \pm 9201.67 \mathrm{IU} / \mathrm{L})$ than in peritoneal fluids $(54.15 \pm 26.26 \mathrm{mg} / \mathrm{dL}, 574.8 \pm 186.54 \mathrm{IU} / \mathrm{L})$ thus concluded that these two parameters could develop a predictor and acceptable tool with significant sensitivity.

\section{Conclusion}

Diagnosis of pleural TB remains a challenge. Among nonconventional tests, ADA and LDH have the best sensitivity and specificity. Limited evidence is available for other novel tests and biomarkers. Combinations of tests seem to perform better than any single test, especially combinations that include ADA, glucose, protein and LDH. The diagnostic usefulness of these tests depends not only on sensitivity and specificity, but also on the local prevalence of TB. The present study shows that simple, inexpensive, highly significant and specific tests like ADA, LDH estimation should be employed routinely to differentiate between tubercular and non-tubercular etiology in patients of pleural effusion. This finding could be helpful in early clinical decision-making for the management of these patients, as it could lead to a better prognosis and avoidance of potential adverse consequences. Further work is necessary to identify the best (and simplest) combination that will be most useful in clinical practice.

\section{Acknowledgements}

The authors are highly thankful for the facilities available at Goverment Medical College Doda, and at Shri Guru Ram Rai Institute of Medical \& Health Sciences and Shri Mahant Indiresh Hospital Patel Nagar, Dehradun.

\section{Ethical clearance}

The study was approved by the ethical committee of the Shri Guru Ram Rai Institute of Medical \& Health Sciences and Shri Mahant Indiresh Hospital Patel Nagar, Dehradun.

\section{References}

1. Kumar V, Abbas AK, Fausto N, Mitchell RN (2007) Robbins Basic Pathology ( $8^{\text {th }}$ ed.). Saunders Elsevier. 516-522.

2. Dye C, Lönnroth K, Jaramillo E, Williams BG, Raviglione M (2009) Trends in tuberculosis incidence and their determinants in 134 countries. Bull World Health Organ 87: 683-691. Link: https://bit.ly/33Q9dTK

3. Implementing the WHO Stop TB Strategy (2008) A handbook for national TB control programmes. Geneva: World Health Organization (WHO) 179. Link: Link: https://bit.ly/2SJpT9f

4. Mehta JB, Dutt A, Harvill L, Mathews KM (1991) Epidemiology of extrapulmonary tuberculosis. A comparative analysis with pre-AIDS era. Chest 99: 1134-1138. Link: https://bit.ly/3jQ7JOQ

5. Gonnella JS, Hudson EK (1966) Clinical patterns of tuberculous peritonitis Archives of Internal Medicine 117: 164-169. Link: https://bit.ly/36VyFcv

6. Seibert AF, Haynes J, Middleton R, Bass JB (1991) Tuberculous pleural effusion. Twenty-year experience. Chest 99: 883-886. Link: https://bit.ly/3iXVoXS

7. Porcel JM (2009) Tuberculous pleural effusion. Lung 187: 263-270. Link: https://bit.ly/3nHMkde

8. Shebl E, Paul M (2018) Parapneumonic Pleural Effusions And Empyema Thoracis. StatPearls Publishing, Treasure Island (FL). Link: https://bit.ly/30XQeVu

9. Porcel JM (2009) Tuberculous Pleural Effusion. Lung 187: 263-270. Link: https://bit.ly/3dirrAi

10. Hillebrand DJ, Runyon BA, Yasmineh WG, Rynders GP (1996) Ascitic fluid adenosine deaminase insensitivity in detecting tuberculous peritonitis in the United States. Hepatology 24: 1408-1412. Link: https://bit.ly/3jSMdZM

11. Riquelme A, Calvo M, Salech F, Valderrama S, Pattillo A, et al. (2006) Value of adenosine deaminase (ADA) in ascitic fluid for the diagnosis of tuberculous peritonitis: A meta-analysis. J Clin Gastroenterol 40: 705-710. Link: https://bit.ly/3jScuaM

12. Mathur PC, tiwari KK, Trikha S, Tiwari D (2006) Diagnostic value of ADA activity in tubercular serositis. Indian Journal of Tuberculosis 53: 92-95. Link: https://bit.ly/33QN1cg

13. Gupta BK, Bhara V, Bandyopadhyay D (2010) Role of Adenosine Deaminase Estimation in Differentiation of Tuberculous and Non-tuberculous Exudative Pleural Effusions. J Clin Med Res 2: 79-84. Link: https://bit.ly/2GG4POz 
14. Krenke R, Korczyński P (2010) Use of pleural fluid levels of adenosine deaminase and interferon gamma in the diagnosis of tuberculous pleuritis. Curr Opin Pulm Med 16: 367-375. Link: https://bit.ly/2GSq8fD

15. Tarn AC, Lapworth R (2010) Biochemical analysis of ascitic (peritoneal) fluid What should we measure? Annals of Clinical Biochemistry 47: 397-407. Link: https://bit.ly/3IFTxZ8

16. Soriano G, Castellote J, Alvarez C, Girbau A, Gordillo J, et al. (2010) Secondary bacterial peritonitis in cirrhosis: a retrospective study of clinical and analytical characteristics, diagnosis and management. J Hepatol 52: 39-44. Link: https://bit.ly/354190P

17. Sahn SA (2012) Getting the most from pleural fluid analysis. Respirology $17:$ 270-277. Link: https://bit.ly/379YFRF

18. Epstein DM, Kline LR, Albelda SM, Miller WT (1987) Tuberculous pleural effusions. Chest 91: 106-109. Link: https://bit.ly/2SZVNyt

\section{Discover a bigger Impact and Visibility of your article publication with} Peertechz Publications

\section{Highlights}

- Signatory publisher of ORCID

* Signatory Publisher of DORA (San Francisco Declaration on Research Assessment)

* Articles archived in worlds' renowned service providers such as Portico, CNKI, AGRIS, TDNet, Base (Bielefeld University Library), CrossRef, Scilit, J-Gate etc.

* Journals indexed in ICMJE, SHERPA/ROMEO, Google Scholar etc.

* OAI-PMH (Open Archives Initiative Protocol for Metadata Harvesting)

* Dedicated Editorial Board for every journal

* Accurate and rapid peer-review process

* Increased citations of published articles through promotions

* Reduced timeline for article publication

Submit your articles and experience a new surge in publication services (https://www.peertechz.com/submission).

Peertechz journals wishes everlasting success in your every endeavours

Copyright: @ 2020 Gupta K, et al. This is an open-access article distributed under the terms of the Creative Commons Attribution License, which permits unrestricted use distribution, and reproduction in any medium, provided the original author and source are credited. 